\author{
A. Serkov ${ }^{1}$, V. Kravets ${ }^{1}$, O. Kasilov ${ }^{1}$, B. Lazurenko ${ }^{1}$, A. Mickus ${ }^{2}$ \\ ${ }^{1}$ National Technical University "Kharkiv Polytechnic Institute", Kharkiv, Ukraine \\ ${ }^{2}$ Vytautas Magnus University, Kaunas, Lithuania
}

\title{
THE CONCEPT OF INFORMATION SECURITY IN THE IOT SYSTEM
}

\begin{abstract}
The subject of the study are the processes of securing information in wireless control and communication channels of the Internet of Things (IoT) system. The goal is to develop the concept of broadband Internet access and the implementation of key security competencies in the implementation of IoT projects. The task is to ensure stable and secure operation of the IoT system. The model is based on the reference model DigComp 2.0, created within the framework of a system of digital competence of citizens. Moreover, the main area of competence of this model is security. The method used: methods of analytical, simulation modeling and temporal position-pulse coding. The following results are obtained: A security concept has been developed in the wireless control and communication channels of the IoT system. It is shown, that to obtain high noise immunity of control and communication channels and to protect information from interception, wireless ultra-wideband communication technology should be used, which allows for large volumes and speeds of information transfer. The possibility of joint interference-free operation in the same frequency range of both traditional narrow-band communication systems and systems using ultra-wideband signals is substantiated. A technical solution for the design of an ultra-wideband receiving - transmitting antenna system is proposed. Conclusions. The use of channels with an ultra-wide frequency band allows for an increase in the number of control and communication channels of the IoT system. Predistribution between the channels of orthogonal codes implements the process of control and communication without interception of information and mutual interference. Moreover, the application of the method of temporal position-pulse coding prevents inter symbol distortions of ultrashort pulses coding. It also reduces the level of distortion of information signals caused by its multipath propagation, which guarantees the security of information in the IoT system.
\end{abstract}

Keywords: IoT system; security; competence; expertise; wireless channel of wireless control and communication channel.

\section{Introduction}

The digitalization of our society requires citizens to be competent in the field of digital technologies for their effective use. Digitalization should provide every citizen with equal access to services, information and knowledge that are provided on the basis of information, communication and digital technologies. In order to overcome the existing different levels of access to services, information and to knowledge, it is necessary to focus on the development of broadband fixed and mobile telecommunications infrastructure, technological infrastructure for IoT projects (Internet of Things) and the development of broadband Internet access [1]. Thus, the main way to implement and effectively use information and communication and digital technologies is the digital competence approach.

\section{System of digital competence}

The system of digital competence of citizens (DigComp) is an effective tool for improving the level of digital competence of specific target groups. In this case, under the competence we understand the possession by a person of a relevant competence, including his personal attitude to it and the subject of activity. This is the potential willingness to solve arising tasks competently and includes substantive and procedural components. It presupposes knowledge of the nature of the problem, the ability to solve it, experience and theoretical and applied preparation for the use of knowledge. This requires constant updating of knowledge, possession of new information for the success of application of this knowledge in specific conditions. Thus, competence is a category that characterizes the degree to which a particular person masters one's scopes, i.e. knowledge and experience of their own activities, allowing them to make judgments and make decisions. Therefore, competence is the basis for the formation and development of expertise.

By the competence one should understand the ability of a person to perform actions and functions of a particular type of activity, which are based on the necessary knowledge, skills, personal qualities and value orientations. These are objective requirements for the professional - personal level of a person performing a certain type of activity. Thus, the category of competence is inherent in the position, and expertise the employee.

In the framework of the developed reference, model (DigComp 2.0) for the system of digital competence of citizens, the main area of competence is security [2]. In this case, the following four groups of competencies are distinguished:

- Protection of devices and security of digital content, understanding of risks and threats in digital environments. Knowledge about safety and security measures. Proper consideration of issues of reliability and individuality.

- Protection of personal data and identity in digital environments. Understanding how to use and share information that allows you to establish an identity, providing the opportunity to protect yourself and others from harm. Understand that digital services use the "Identity Policy" to understand how personal data is used.

- Protection of health and well-being. Ability to avoid risks to health and threats to physical and psychological well-being when using digital technologies. Be able to protect yourself and others from possible threats in digital environments (for example, from cyber threats). Know about digital technologies to ensure social well-being and social integration. 
- Environmental protection. Awareness of the impact of digital technologies and their influence on the environment.

These competences in the structure of the general digital competence of citizens are closely interrelated. Therefore, each of them can influence the development of others. Thus, the implementation of these core competencies in the implementation of Internet of Things projects and the organization of broadband Internet access will ensure equal and secure access of citizens to services, information and knowledge.

\section{Task solution}

The concept of the Internet of Things (IoT) allows you to improve the quality of life and human activity, the efficiency of production, government services and utilities. IoT is a series of physical devices placed in a limited space, interconnected by the Internet and a user of wireless communication channels. It involves the creation of an apartment and office management system that integrates all the engineering systems of fire alarm, security, power supply and lighting. The goal of this concept is to provide flexible management, economical use of resources, as well as creating a comfortable and safe indoor environment. This area also includes software that allows the interaction of physical things with computer systems and networks, including the Internet. The system makes it possible at the household level to remotely control these physical devices, as well as to accumulate, extract and transmit information. Moreover, the control algorithms, in general, are defined by the user in an arbitrary way.

Thus, the integration of individual devices into an IoT system turns it into a complex dynamic system that functions under conditions of substantial a priori uncertainty and randomly organizes the interaction of its heterogeneous constituent elements. The distinctive ability of these systems is the concentration in a limited, usually closed space of a large number of sources of electromagnetic radiation having a different amplitudefrequency range. The presence of such a complex electromagnetic environment in a closed confined space complicates the high-quality operation of the elements of the IoT system, causing failures in control systems and communication channels. In this case, there is a real possibility of unauthorized access to information circulating in the system and the probability of unauthorized interception of the control channel of individual elements of the system increases.

Thus, ensuring sustainable and secure operation of the IoT system is an urgent task.

By noise, immunity of the control system and / or communication channel is meant the maximum level of electromagnetic interference at which it maintains the required quality of work. The encoding of information in the channels of information and control can increase noise immunity. In the presence of external influencing factors, the use of well-known algebraic, iterative, cascade convolutional and other codes, as well as methods for their decoding [5], require redundancy, which leads to a decrease in the speed of information transmission. At the same time, the need to increase the speed of transmission of control signals in wireless channels requires the use of the widest possible frequency range. Thus, the known methods of information encoding in wireless control and communication channels do not provide the necessary noise immunity level, which means that further development requires the creation of new approaches to solving this problem. The physical limitation of the frequency spectrum has led to the need to apply ultrawideband technologies (UWBS).

In wireless control and communication channels, the transmission medium is the physical path between the transmitter and the receiver. However, when determining the characteristics of information transfer, the medium itself is not a more important factor, but the bandwidth of the emitted signal. The most common and optimal range for wireless control and communication systems is from 1 to $10 \mathrm{GHz}$. [6]. This is due to the fact that at frequencies below $1 \mathrm{GHz}$ there is significant interference from various electronic devices. At the same time, at frequencies above $10 \mathrm{GHz}$, signal absorption by the transmission medium is large.

When using broadband transmission, a deliberate conversion of relatively narrowband information signals with an efficiently transmitted spectrum width $\Delta f$ in to a wideband signal with a broad bandwidth $\Delta F$ while maintaining total energy $E$ of a signal. In this case, the spectral energy density of the channel signal is intentionally reduced by $\Delta F / \Delta f$ times, and which will make $\Delta E / \Delta F$, and the base of the channel signal will increase by $\Delta F / \Delta f$ times. The basis of the ultrashort pulse of UWBS is the product of the signal duration and the width of its spectrum. The simplest and most convenient method for expanding the base of a signal is direct expansion of the frequency spectrum. Moreover, the higher the frequency used, the higher the potential data transfer rate. Thus, UWBS technology consists in transmitting low-power coded pulses in a very wide frequency band without a carrier frequency. In this case, not a harmonic oscillation is emitted, but an ultrashort pulse, the duration of which lies in the range of $0.2-2.0$ $\mathrm{nS}$, and the period of the pulse sequence is $10-100 \mathrm{nS}$. Typically, such signals have the form of idealized Gaussian monocycles, the main part of the emission spectrum of which is in the frequency range from 1 to $10 \mathrm{GHz}$ [6]. Therefore, if we use as a coding pulse Gauss monocycle with a duration of $\Delta t$ from $2.0 \mathrm{nS}$ up to $0.1 \mathrm{nS}$ and the power spectrum bandwidth will be respectively from $500 \mathrm{MHz}$ to $10 \mathrm{GHz}$. And the spectrum of the signal will occupy the entire frequency band from 0 to $\Delta F \approx 1 / \Delta t$.

In the control and communication channel, information is encoded by means of temporal positionpulse modulation [7]. So the pulse offset relative to the reference forward position in the sequence sets the "zero" bit, and backward - sets "one". The offset time does not exceed a quarter of the pulse duration, and, one information bit is encoded by a sequence of many pulses per bit. To separate information communication channels, the position of each pulse is shifted by a time proportional to the current value of a certain pseudorandom sequence. Moreover, the shift time is one to two 
orders of magnitude higher than the shift during time modulation. Each channel is assigned its own spreading code combination, the elements of which constitute the orthogonal basis and specify the channel code. And the decoding of the information message is carried out only if the receiver and transmitter use the same channel code, which increases the noise immunity of signals in a wireless control and communication system.

The selection of the useful signal in the background noise is carried out by the correlation of the received and reference signals. The correlator performs a convolution of the received signal from the reference one. It is an ideal detector for determining the time shifts of received pulses relative to the reference. So when receiving a unit, the correlation function is +1 , and when receiving 0 , it takes the value - 1 . In all other cases, the correlation function is 0 . And since the information bit is represented, for example, by 200 ultrashort pulses, then if the code coincides, they accumulate in the integrator receiver and the bit will be detected correctly, even if 99 pulses out of 200 will be spoiled. The useful signal stands out from the noise level, significantly exceeding its signal-to-noise ratio. In this case, the coding of the information bit by a series of ultrashort pulses eliminates the problem of multipath propagation of the signal, since the signal arriving with a time shift due to different paths will be discarded as an interfering signal. At the same time, the use of a series of ultrashort pulses to encode the information bit makes it possible to eliminate intersymbolic interference. This is due to the fact that before the passage of the next ultrashort pulse from the coding series, the energy of the previous pulse has time to completely dissipate.

Due to the fact that coded pulse signals are to be transmitted in a very wide frequency band without a carrier frequency, fulfilling the requirements for broadband receiving and transmitting antennas is critical. The technical characteristics of the most acceptable is the antenna element [8], which is an antenna with an expanding slot (Tapered Slot Antenna - TSA). The shape of the open slit determines the frequency band, and the energy pattern of the antenna is characterized by a narrow main beam and almost no side lobes. However, the preliminary formation of an UWBS (Gaussian monocycle) that is fed to the antenna system causes coordination difficulties in a wide frequency range. This is manifested in the form of the reflections of individual components of UWBS that distort the shape of the Gaussian monocycle.

In the proposed technical solution [9]. information monopulse signal is divided in half. One part of the signal is successively inverted and delayed by a time equal to half the duration of the single pulse. Then, using both monopulse signals, excite respectively two adjacent TSA antennas on a single dielectric base. The electromagnetic fields of two unipolar pulses - the main and inverted - interfere in the equivalent common space of the aperture of the antennas, creating in it the electromagnetic field of the bipolar pulse, which is an ultra-wideband pulse signal. This eliminates the time interval between the two parts of the radiated field, which is typical of a single-pulse TSA antenna.

\section{Analysis}

It should also be noted that the ultra-wideband pulsed antenna is capable of emitting both an ultrashort unipolar mono-pulse and a bipolar-pulsed information signal. Moreover, the proposed technical solution can significantly increase the range of propagation of pulsed electromagnetic signals. So, compared to the radiation level of a unipolar pulse signal, the propagation distance of a bipolar pulse generated in the aperture of the antenna increases by 9.5 times, and compared to the monochromatic signal - by 2.37 times [8].

\section{Conclusions}

The use of technology of ultra-wideband signals in the control and communication channels makes it possible to obtain a number of advantages that cannot be achieved by traditional methods. In particular, this refers to improving the quality indicators of the control channels. The expansion of the communication channel bandwidth and the transition to channels with an ultrawide bandwidth allows for an increase in the number of communication channels. Distributing modulation codes between channels in advance, they are controlled without interception of control and mutual interference.

The most important criterion characterizing the effectiveness of wireless communication systems is the high potential specific data transfer density. It is defined as the value of the achievable total data transfer rate per square meter of the working area and has today the value of this indicator - about $1 \mathrm{Mbit} / \mathrm{s} / \mathrm{m}^{2}$. The use of short pulses prevents intersymbol distortions, since the energy of a received pulse usually has time to almost completely fade before the next pulse arrives. This also reduces the level of distortion of information signals caused by its multipath propagation. A major feature inherent in control and communication systems based on ultra-wideband signals is the low probability of detecting both the fact of the temporary establishment of a communication channel and the impossibility of intercepting a control channel. Simultaneous noise-free operation in the same frequency range of both traditional narrow-band communication systems and UWBS systems is due to the fact that the level of the control signal does not exceed the noise level in the working frequency range. At the same time, the reduction in power and radiation level of electromagnetic fields makes it possible to guarantee that the requirements of electromagnetic compatibility are met at all stages of the development and implementation of control and communication systems.

\section{Acknowledgment}

This work was partially funded by the European Union in the context of the "dComFra - Digital competence framework for Ukrainian teachers and other citizens" project (Project Number: 598236-EPP-1-20181-LT-EPPKA2-CBHE-SP) under the ERASMUS + program. The European Commission's support for the creation of this work is not an endorsement of the content that reflects only the views of the authors, and the Commission cannot be held responsible for any use of the information contained in this work. 
REFERENCES

1. Vuorikari, R., Punie, Y., Carretero Gomes S. and Van den Brande, G. (2016), DigComp 2.0: The Digital Competence Framework for Citizens, Update Phase 1: The Conceptual Reference Model. Luxembourg Publication Office of the European Union, EUR 27948 EN, DOI: https://doi.org/10.2791/11517

2. CMU (2018), The Concept of the Development of the Digital Economy and Society of Ukraine for 2018-2020, Order of the Cabinet of Ministers of Ukraine dated January 17, 2018 p. № 67-p., available at: https://www.kmu.gov.ua

3. Digital Agenda of Ukraine - 2020 (2016), Conceptual foundations. Priority areas, initiatives, projects of "digitalization" of Ukraine up to 2020, available at: https://ucci.org.ua/uploads/files/58e78ee3c3922.pdf

4. International Standard IEC 1000-4-92 (1992), Immunity tests. Resistant to interference. Level of noise immunity.

5. Gallager, R.G. (1974), Information Theory and Reliable Communication, Soviet Radio, Moscow, 720 p.

6. Harmuth, H.F. (1981), "Non sinusoidal Waves for Radar and Radio Communication", Academic Press, New York, London, Toronto, Sydney, San Francisco, 376 p.

7. Serkov, A., Breslavets, V., Tolkachov, M. and Kravets V. (2018), "Method of coding information distributed by wireless communication lines under conditions of interference", Advanced Information Systems, Vol. 2, No.2, pp. 145-148, DOI: https://doi.org/10.20998/2522-9052.2018.2.25

8. Serkov, O., Breslavets, V., Tolkachov, M. and Churyumov G. (2018), "The Wideband Pulsed Antenna and its Application", 9-th Inter. Conf. on Ultrawideband and Ultrashort Impulse Signals (UWBUSIS-2018)], Odessa, pp. 340-343.

9. Serkov, O.A., Breslavets, V.S., Tolkachov, M.Yu. and Churyumov G.I. (2018), "Method of Generation the Wideband Impulse Signals and Antenna for his Realization”, Patent of Ukraine No. 2018/03104.

Received (Надійшла) 19.01.2019

Accepted for publication (Прийнята до друку) 27.02.2019

\section{Концепція безпеки інформації в системі Іот}

\section{О. А. Серков, В. О. Кравець, О. В. Касілов, Б. О. Лазуренко, Артурас Міцкус}

Предметом вивчення $\epsilon$ процеси забезпечення безпеки інформації в безпроводових каналах управління та зв'язку системи Internet of Things (IoT). Мета - розробка концепції організації широкосмугового доступу до Інтернету та реалізація ключових компетенцій безпеки під час виконання проектів ІоТ. В основу моделі покладено еталонну модель DigComp 2.0, яку створено в рамках системи цифрової компетентності громадян. Причому, основною сферою компетентності цієї моделі є безпека. Задача - забезпечення усталеної та безпечної роботи системи ІоТ. Використані методи: методи аналітичного, імітаційного моделювання та часового позиційно-імпульсного кодування. Отримані наступні результати. Розроблена концепція забезпечення безпеки в безпроводових каналах управління та зв'язку системи ІоТ. Показано, що для отримання високої завадостійкості каналів управління і зв'язку та захисту інформації від перехоплення слід застосовувати технологію безпроводового надширокосмугового зв'язку, яка дозволяє забезпечити великі обсяги та швидкості передачі інформації. Обгрунтовано можливість сумісної беззавадової роботи в одному частотному діапазоні як традиційних вузькосмугових систем зв'язку, так і систем, які використовують надширокосмугові сигнали. Запропоновано технічне рішення щодо конструкції надширокосмугової приймальнопередавальної антенної системи. Висновки. Використання каналів із надширокою смугою частот дає можливість практично необмеженого збільшення кількості каналів управління та зв'язку системи ІоТ. Попередній розподіл між каналами ортогональних кодів реалізує процес управління та зв'язку без перехоплення інформації та взаємних завад. Причому, використання методу часового позиційно-імпульсного кодування запобігає виникненню міжсимвольних спотворень кодуючих надкоротких імпульсів. При цьому також знижується рівень спотворень інформаційних сигналів, які викликані його багатопроменевим розповсюдженням, що гарантує безпеку інформації в системі IоT.

Кл юч о в і сл о в а : система ІоТ; безпека; компетенція; компетентність; безпроводовий канал управління та зв’язку.

\section{Концепция безопасности информации в системе ІоТ}

\section{А. А. Серков, В. А. Кравец, О. В. Касилов, Б. А. Лазуренко, Артурас Мицкус}

Предметом изучения являются процессы обеспечения безопасности информации в беспроводных каналах управления и связи системы Internet of Things (IoT). Цель - разработка концепции организации широкополосного доступа к Интернету и реализация ключевых компетенций безопасности при выполнении проектов IоТ. В основу модели положена эталонная модель DigComp 2.0, созданная в рамках системы цифровой компетентности граждан. Причем, основной сферой компетентности этой модели является безопасность. Задача - обеспечение устойчивой и безопасной работы системы ІоТ. Используемые методы: методы аналитического, имитационного моделирования и временного позиционно-импульсного кодирования. Получены следующие результаты. Разработана концепция обеспечения безопасности в беспроводных каналах управления и связи системы ІоТ. Показано, что для получения высокой помехоустойчивости каналов управления и связи и защиты информации от перехвата следует применять технологию беспроводной сверхширокополосной связи, которая позволяет обеспечить большие объемы и скорости передачи информации. Обоснована возможность совместной безпомеховой работы в одном частотном диапазоне как традиционных узкополосных систем связи, так и систем, использующих сверхширокополосные сигналы. Предложено техническое решение по конструкции сверхширокополосной приемо-передающей антенной системы. Выводы. Использование каналов со сверхширокой полосой частот дает возможность практически неограниченного увеличения числа каналов управления и связи системы IоT. Предварительное распределение между каналами ортогональных кодов реализует процесс управления и связи без перехвата информации и взаимных помех. Причем, применение метода временного позиционно-импульсного кодирования предотвращает межсимвольные искажения кодирующих сверхкоротких импульсов. При этом также снижается уровень искажений информационных сигналов, вызванных его многолучевым распространением, что гарантирует безопасность информации в системе IоT.

Ключевые слова : система ІоТ; безопасность; компетенция; компетентность; беспроводной канал управления и связи. 